\section{Economic growth and financial performance of Islamic banks: a CAMELS approach}

\author{
Mohammed Ayoub Ledhem and Mohammed Mekidiche \\ Department of Economics, University Centre of Maghnia, Maghnia, Algeria
}

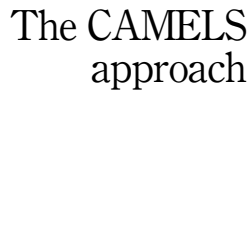

\begin{abstract}
Purpose - The purpose of this paper is to investigate the link between the financial performance of Islamic finance and economic growth in all of Malaysia, Indonesia, Brunei, Turkey and Saudi Arabia within the endogenous growth model framework.

Design/methodology/approach - This study applied dynamic panel system GMM to estimate the impact of the financial performance of Islamic finance on economic growth using quarterly data (2014:1-2018:4). CAMELS system parameters were employed as variables of the financial performance of Islamic finance and gross domestic product (GDP) as a proxy of economic growth. The sample contained all Islamic banks working in the five countries.

Findings - The findings demonstrated that the only significant factor of the financial performance of Islamic finance, which affects the endogenous economic growth, is profitability through return on equity (ROE). The experimental findings also indicated the necessity of stimulating other financial performance factors of Islamic finance to achieve a significant contribution to economic growth.

Practical implications - The analysis in this paper would fill the literature gap by investigating the link between financial performance of Islamic finance and economic growth, as this study serves as a guide for the academians, researchers and decision-makers who want to achieve economic growth through stimulating Islamic finance in the banking sector. However, this study may well be extended to investigate the link between the financial performance of Islamic finance and economic growth over the Z-score model as another measure for the financial performance of Islamic finance.

Originality/value - This paper is the first that investigates the link between financial performance of Islamic finance and economic growth empirically using CAMELS parameters within the endogenous growth model to provide robust information about this link based on a sample of the top pioneer Islamic finance countries.
\end{abstract}

Keywords Islamic finance, Financial performance, Economic growth, CAMELS model, Endogenous growth model, Panel system GMM

Paper type Research paper

\section{Introduction}

Islamic finance has been one of the fastest rising industries over the last ten years, which was estimated to be worth US $\$ 2.4$ trillion in 2017 and forecast to grow by $6 \%$ CAGR to reach US\$3.8 trillion by 2023 (Reuters, 2020). This optimistic tall growth degree of Islamic finance assets year after year attracts the attention of all policymakers, bankers and financial academics to look into the Islamic finance industry. Lately, in the last decade, one of the main debates among financial scholars and policymakers besides the relationship between Islamic finance and economic growth is whether the financial performance of Islamic finance contributes to economic growth. According to Bourke (1989), high profitability banks persist well-capitalized and their access to funds is easy.

\section{JEL Classification — C23, G21, G32, O47. KAUJIE Classification - I3, I5, L4}

(C) Mohammed Ayoub Ledhem and Mohammed Mekidiche. Published in Islamic Economic Studies. Published by Emerald Publishing Limited. This article is published under the Creative Commons Attribution (CCBY 4.0) license. Anyone may reproduce, distribute, translate and create derivative works of this article (for both commercial and non-commercial purposes), subject to full attribution to the original publication and authors. The full terms of this license may be seen at http://creativecommons. org/licences/by/4.0/legalcode
Received 12 May 2020 Revised 24 June 2020 Accepted 9 July 2020 
IES

28,1

Certainly, the financial institutions that operate well play a weighty role in economic growth and financial performance (Rabaa and Younes, 2016). Moreover, the banking sector performance and profitability power the economy's growth and boost it to contain negative shocks, also Bikker and $\mathrm{Hu}$ (2002) and Demirgüç-Kunt and Huizinga (1999) have stated a positive supportive relationship between economic growth (GDP) and the performance of banks. Furthermore, according to Tabash and Anagreh (2017), Islamic banks have effected significantly the growth of GDP and investments of countries in the Middle East.

Currently, the Islamic banking sector comprises $71 \%$ of all Islamic finance assets with a portion of 1.721 trillion US\$ (Islamic Finance Development Report 2018, 2018; Reuters, 2020) and could reveal its stability in and after the 2008 global financial crisis (Tabash and Dhankar, 2014; Olson and Zoubi, 2017).

According to Reuters (2020), Malaysia is the leading country in Islamic finance's best performance with a Global Islamic Economy Indicator (GIEI) score equal to 111 and an Islamic Finance Development Indicator (IFDI) score equal to 132 according to Islamic Finance Development Report 2018 (2018). Besides, Brunei and Indonesia were the most improved performers in Southeast Asia, Brunei was the biggest gainer in Southeast Asia and finished in 9 th position with an IFD indicator score of 50 while Indonesia ranked 10th. Moreover, the 2018 global Islamic economy report stated that Saudi Arabia ranked fourth as one of the best Islamic finance countries with a GIE indicator score of 54, while Turkey ranked in the top 15 countries with a GIE indicator score of 31 (State of the Global Islamic Economy Report 2018/ 19, 2018).

Furthermore, this enormous success of the Islamic finance industry in Malaysia, Indonesia, Brunei, Turkey and Saudi Arabia synchronized a high level of economic growth, while Malaysia economy enhanced 4.9\% year-on-year in the second quarter of 2019, succeeding a $4.5 \%$ rise in the earlier three-month cycle and a $4.8 \%$ spreading business prospects (Trading Economics Report, 2019a), although Indonesia economy is predictable to expand at $5.1 \%$ in 2019 and then increase to $5.2 \%$ by 2020 (World Bank, 2019). In addition, Brunei GDP rose by 0.1\% compared with 2017 (Brunei GDP - Gross Domestic Product 2018, 2018). While the GDP in Turkey rose by $1.20 \%$ over the previous quarter in the second quarter of 2019, the GDP growth rate in Turkey ranged 1.09\% between 1998 and 2019 (Trading Economics Report, 2019b). Although GDP in Saudi Arabia extended 1.66\% year-onyear in the opening quarter of 2019, it diminished from $3.59 \%$ in the previous period (Trading Economics Report, 2019c).

Because of the limited studies that investigated the link between financial performance of Islamic finance and economic growth and the lack of understanding this link (Tabash, 2019), the contribution of this study is to investigate this link in a framework of endogenous growth model through international evidence from Malaysia, Indonesia, Brunei, Turkey and Saudi Arabia as the top pioneer Islamic finance countries. Therefore, this study answers the following question: "Does the financial performance of Islamic finance affect economic growth in the frame of the endogenous growth model?"

\section{Literature review}

Banking performance and economic growth

Endogenous growth theory was established in the 1980s by Romer; the endogenous growth model is described with the lasting growth pace which well-defined by factors inside the model and not by the exogenous degree of technological advancement as in the neoclassical growth model (Romer, 2011). Jhingan (2011) clarified that the endogenous growth model reinforces technical evolution emerging from the investment degree and the human capital stock size, and both Tabash and Anagreh (2017) have confirmed that Islamic finance has affected significantly the economic growth and investments of countries in the Middle East. 
Thus, based on the endogenous growth model, when investments are increased due to the finance and banking performance that leads to higher economic growth (Petkovski and Kjosevski, 2014). Moreover, Bourke (1989) has confirmed that banks with higher profitability keep on strongly capitalized and have fast access to funds. As a result, the increase in capital stock in the banking sector due to the banking and finance profitability leads to economic growth according to the endogenous growth theory. In conclusion, economic growth is determined by banking sector performance because of its significant impact on increasing investments and capital stock.

\section{CAMELS system}

CAMELS is an acronym for six parameters, capital adequacy $(\mathrm{C})$, asset quality $(\mathrm{A})$, management efficiency $(\mathrm{M})$, earnings $(\mathrm{E})$, liquidity $(\mathrm{L})$ and sensitivity to the market risk (S), to measure the banking and finance performance (Wanke et al., 2016). As it is shown in Table 1, CAMELS is an extended approach to the CAMEL model which has been used in the USA since 1979 to judge the soundness of banks (Christopoulos et al., 2011; Roman and Şargu, 2013). Later, CAMEL has been extended and used as a method to assess the soundness and financial performance of banks for the supervisory authorities in different countries (Roman and Şargu, 2013). The financial weakness and soundness were measured by the International Monetary Fund (IMF) using five major handful parameters of financial system soundness with shortening of CAMEL (capital adequacy, asset quality, management quality, earnings size and liquidity). Nevertheless, it has been extended to include the sixth parameter "S" which reflects the bank sensitivity to the deviations in the market (Roman and Şargu, 2013). This "S" measures the sensitivity to market risks like interest rate, foreign exchange and inflation risk which captures the organization's risk (Gasbarro et al., 2002; Karim et al., 2018). Currently, CAMELS becomes an evaluation tool for bank performance (Roman and Şargu, 2013). According to the report of IMF (2000), the IMF and world bank advocated the use of CAMELS as a valuable measure for financial system stability.

\section{Previous empirical studies}

Pure studies on the financial performance and economic growth nexus are limited, most of them have agreed on that there is a link between financial performance of the banking sector

\begin{tabular}{ll}
\hline Parameter & Definition \\
\hline Capital adequacy (C) & $\begin{array}{l}\text { Capital Adequacy is a calculation of the capital required to control the risk based on } \\
\text { the bank asset value } \\
\text { Asset quality is the instability of soundness banking induced by unsettled bank } \\
\text { Asset quality (A) }\end{array}$ \\
$\begin{array}{l}\text { Management efficiency affected by high nonperforming loans } \\
\text { Management measures the efficiency of the company to minimize and reduce costs } \\
\text { Earnings (E) }\end{array}$ & $\begin{array}{l}\text { Earning is a measure of profitability and there is an assessment of earnings and } \\
\text { their level of relationship with peers in which the objective is to evaluate the effect } \\
\text { of internally produced funds on the capital of the bank }\end{array}$ \\
$\begin{array}{l}\text { Liquidity is the capacity and ability of banks to repay and reimburse short-term } \\
\text { obligations } \\
\text { Sensitivity to market risk is the measure of how resilient the assets, liabilities and } \\
\text { net worth values of the bank are to changes in market conditions such as rate of } \\
\text { interest, foreign exchange and inflation risk }\end{array}$
\end{tabular}

Source(s): Retrieved from (Sahut and Mili, 2011; Altan et al., 2014; Peltonen et al., 2015; Munir et al., 2017; Karim et al., 2018)
The CAMELS approach

\section{$+$}


IES

28,1

50

and economic growth of any country, but all of them were focused only on the conventional banking sectors. Therefore, this study is one of the limited studies that investigate the link between financial performance of Islamic finance and economic growth, and it is the first that linked the financial performance of Islamic finance in a structure of CAMELS model with economic growth in a framework of endogenous growth. Thus, it is believed that this study will make a noteworthy contribution to the literature.

In a study, Rabaa and Younes (2016) surveyed the influence of the financial performance of Islamic Banks on the economic growth in terms of financial liberalization through the use of Islamic banks in all of Abu Dhabi, Saudi Arabia, Bahrain, Great Britain and Tunisia over the period 2001-2012. They used panel fixed effect and GLS regression with variables of GDP, return on assets (ROA), return on equity (ROE), a ratio of the performance of Zakat, a ratio of Islamic earnings vs. not Islamic earnings, industrial production index (IPI), consumer price index (CPI) and money market rate. They resolved that Islamic banking performance had a significant influence on economic growth.

Tabash (2019) also came to a similar conclusion, which found that there is a constructive significant relationship between financial performance of Islamic banks and economic growth in the UAE; he used pooled ordinary least square with variables of GDP, ROA, ROE and the net revenue margin (NRM) on a sample of all full-sized active Islamic banks in the UAE covering a period from 2000 to 2014.

In the same vein, Alkhazaleh (2017) demonstrated the correlation between the financial performance of commercial banks in Jordan and economic growth. He used (ROA), deposits and credit facilities as independent variables, and GDP as a dependent element. He used the pooled regression examination to test the associations between variables. He settled that commercial banks' performance contributes to the economic growth in Jordan.

In another empirical study of evaluating how profitability which is the main proxy for the financial performance in the banking sector influences Nigeria's economic growth, Adekola (2016) showed the existence of a straight connection between banks' profitability and economic growth in Nigeria. He used a pooled regression technique for all banks occupied in Nigeria under the period 2005-2014 using the GDP, ROE and return on capital employed (ROCE).

In a similar study, Yazdani (2011) explored the effect of private banks' financial performance on economic growth in Iran. He adopted GDP, ROA, cash and investments as research variables. His results showed that bank performance had a positive effect on the economic growth of Iran.

Concerning studies of the financial performance of Islamic finance determinants measured by the profitability, Khan et al. (2014) have examined factors that affect Islamic banking profitability which was adopted as a measure for the financial performance in Pakistan. They employed a sample of five Islamic banks in Pakistan from 2007 to 2014. They employed capital adequacy ratio, bank size, nonperforming loans (NPL) ratio, gearing ratio, asset composition, operational efficiency, asset management, deposit ratio, (GDP) and (CPI) as exogenous variables, ROE, ROA, earnings per share (EPS) as endogenous variables. Their results showed that the profitability of Islamic banking was impacted by bank-specific aspects such as asset management, NPL ratio, deposit ratio and exterior factors such as CPI.

Further, Djalilov and Piesse (2016) have investigated bank financial performance with profitability determinants in the early transition countries of Central and Eastern Europe; they applied GMM system, random-effects regression on a sample of 275 banks from 16 transition economies, eight are from the ex-Soviet Union, other countries are from the CEE and the States of Baltic covering the period of 2000-2013. They adopted capital, credit risk, cost, bank size, bank market share, GDP growth, inflation, government spending, fiscal freedom, monetary freedom as independent variables, and ROA as the dependent variable. They noticed that the effect of credit risk on bank profitability in the early transition countries 
was favorable, and government spending and well-capitalized banks in the early transition countries were more competitive.

In another special case of Indonesia, Setyawati et al. (2017) evaluated both of internal and external factors affecting the financial performance of Islamic banking. They applied panel multiple regression on a sample of all the Islamic banks in Indonesia for a period ranging from 2004 to 2012 and adopted internal determinants (NPF, capital strength (CS), external determinants (GDP, inflation, dummy variable of the financial crisis) as independent variables, and ROA as a dependent variable. Their findings revealed that the performance of Islamic banks has been greatly affected by nonperforming finance and inflation, and has been much better since the crisis.

Moreover, Alharbi (2017) studied the determinants of the financial performance of Islamic banks through profitability using a simple of 110 Islamic banks in 25 countries that were members in the Organization of Islamic Cooperation (OIC) from 1992 to 2008 by applying panel fixed-effects regression; he used all of Islamic banks profitability, return on assets average (ROAA), internal variables (operating income (OOI), capital ratio), external variables (GDP per capita, GDP and oil) and regulation variables of bank taxation and financial structure (market capitalization to GDP) as independent variables, and net profit revenue average over earning assets as the dependent variable. His results indicated that equity, bank size, operating income, oil prices and GDP per capita had a positive impact on Islamic banks.

Another study of Zarrouk et al. (2016), they investigated whether Islamic banks profitability is motivated by the same factors of conventional banks in the MENA. They used panel system GMM on a simple of 51 Islamic banks in all of Jordan, UAE, Turkey, Egypt, Yemen, Kuwait, Sudan, Bahrain, Saudi Arabia and Qatar from 1994 to 2012, and they adopted bank-specific factors (risk and solvency, efficiency ratios, liquidity, asset quality, annual stock data and capital), macroeconomic factors (gross domestic product, consumer price index, investment ratio of GDP, dummy variable of inflation) as exogenous variables and profitability ratios (ROA, ROE, NPM) as dependent variables. They resolved that profitability was affected by the asset quality, cost-effectiveness and capitalization of both banks.

Another similar study of Olson and Zoubi (2017), they examined whether the global financial crisis $(\mathrm{GFC})$ led to the convergence of the financial performance of Islamic and commercial banks in the MENASA region (22 countries) from 1996 to 2014, and they applied dynamic panel model using performance ratio which is the ROA as an endogenous variable, bank-specific accounting ratios such as ROE and financial variables as independent variables; they stated that Islamic banks firstly weathered the outbreak of the global financial crisis better than conventional banks in 2007-2008.

Regarding studies that have used CAMELS model to measure and analyze the banking financial performance, most of them have found that the CAMELS is pretty useful in terms of arbitrating the financial performance, Rashid and Jabeen (2016) examined the determinants of both Islamic and commercial banks in Pakistan; they have created the financial performance index (FPI) based on CAMELS ratios and then applied the calculated index on the CAMELS determinants. They applied GLS regression on an unbalanced yearly panel data covering the period 2006-2012. Operating efficiency, reserves and overheads were found to be significant factors in the performance of conventional banks, while operating efficiency, market concentration, and deposits were significant at explaining Islamic bank performance.

Similarly, Rashid et al. (2015) assessed the financial performance of Islamic banks and conventional banks in Pakistan using the CAMELS system to assemble the FPI. Their results demonstrated that the financial performance of Islamic banks was better in 2012 comparing to 2006 .

Another study of Rodica-Oana (2014) used CAMELS approach to detect the development of the banking system in Romania for the period of pre-crisis before 2007 and post-crisis after 
IES

28,1

52

2007; the study concluded that there are cross-sectional effects between the banking indicators that contributed a cautionary signal about the evolution of the banking system. Another similar study of Karim et al. (2018), they used all of CAMELS model and Z-score to measure the stability of 50 banks in Malaysia from 1999 to 2015; they found that both Islamic and commercial banks were satisfactorily listed on a general bank solidity scale.

An additional study of Masood et al. (2016), they applied the CAMELS rating model to evaluate the performance of the operating Islamic banks in Pakistan for the year 2015. They found that two of the Islamic banks had a good position, while the others were in a reasonable position.

Another equivalent study, Rostami (2015) applied CAMELS model to assess the Iranian bank performance for the period of 2009-2014. The results indicated that CAMELS is an effective tool to judge the bank performance.

In the same frame, Rozzani and Rahman (2013) examined the performance of both the Islamic and conventional banks in Malaysia between 2008 and 2011. Their results showed that performance levels were extremely parallel for both the conventional and Islamic banks.

Concerning studies of Islamic finance and economic growth nexus, Kassim (2016) explored the effect of Islamic finance on the performance of important macroeconomic indicators on a sample of all Islamic banks in Malaysia covering a quarterly period from 1998 to 2013 by applying the ARDL approach. Kassim (2016) adopted industrial production index (IPI) as a proxy for economic growth and total deposit of the Islamic banks, total financing by Islamic banks, gross fixed capital formation, general government expenditure and inflation as independent variables. The results revealed that by funding investment projects, Islamic banking system contributes to the real economy. Besides, Boukhatem and Moussa (2018) presented clear empirical evidence that the implementation of the Islamic financial system has stimulated economic growth in the 13 selected MENA region; they applied panel cointegration and FMOLS regression on a sample of Islamic banks in the MENA region for a period ranged from 2000-2014, and they used GDP per capita growth as dependent variable and loans by Islamic banks/GDP, education, inflation, government consumption/GDP, trade openness, domestic credits to private sector/GDP, regulatory quality and rule of law as independent variables.

This study adopted, according to the literature, the most appropriate empirical model and the most common variables for both the financial performance of Islamic finance and economic growth determinants. Moreover, unlike the previous studies, this research associated the financial performance of Islamic finance within a structure of the CAMELS model with the economic growth in a framework of endogenous growth; therefore, this is the first study that examines the link of the financial performance of Islamic finance and economic growth with this methodology. Thus, it is believed that the results were more effective and accurate than other studies.

\section{Research methodology \\ Sample and data collection}

This study used a balanced panel data of all full-fledged Islamic banks working in five countries of Malaysia (16 Islamic Banks), Indonesia (11 Islamic Banks), Brunei (two Islamic Banks), Turkey (four Islamic Banks) and Saudi Arabia (four Islamic Banks) covering a period range from the first quarter of 2014 until the last quarter of 2018 (2014Q1 to 2018Q4). The data of Islamic finance were drawn from quarterly datasets of the Islamic Financial Services Board (IFSB) database. Other data were collected from the IMF database, the Indonesian central bank and the Brunei Ministry of finance and economy. Since all countries (Malaysia, Indonesia, Brunei, Turkey and Saudi Arabia) have different currencies, all the quarter financial values were converted in the US dollar using proper average exchange rates according to the IMF database for each quarter. 
Experimental variables

Financial performance of Islamic finance variables based on CAMELS model. Table 2 shows all the variables of the financial performance of Islamic finance based on the CAMELS model.

Concerning earning ability in CAMELS model, we have focused on this parameter by using three major indicators since most studies have focused on the profitability (earnings) by using three earning indicators of ROA, ROE and NPM as proxies for the financial performance of banking and finance, ROA and ROE based on the literature (Yazdani, 2011; Khan et al., 2014; Adekola, 2016; Djalilov and Piesse, 2016; Rabaa and Younes, 2016; Zarrouk et al., 2016; Alharbi, 2017; Olson and Zoubi, 2017; Setyawati et al., 2017; Tabash, 2019), in which higher ratios of ROA and ROE indicate better performance (Zarrouk et al., 2016).

The third indicator is NPM (or net revenue margin), according to the studies of (Yazdani, 2011; Zarrouk et al., 2016; Alharbi, 2017; Olson and Zoubi, 2017; Tabash, 2019) in which net profit margin (NPM) explores the effectiveness of bank investment decisions related to its debt situations and represents the efficacy of the intermediation of bank funds (Zarrouk et al., 2016). Thereby, the higher (NPM) ratio also reveals better financial performance. Whereas, the remaining parameters of the CAMELS model were adopted by a single individual indicator based on the previous studies as shown in (Table 2).

The economic growth variable. All reviews in this study have settled on the use of GDP as a proxy for economic growth when it is analyzed with the financial performance of Islamic finance. Thus, this empirical study has adopted the GDP as a proxy independent variable for economic growth.
The CAMELS approach

53

\begin{tabular}{|c|c|c|}
\hline $\begin{array}{l}\text { CAMELS } \\
\text { parameters }\end{array}$ & CALCULATION & literature (source) \\
\hline $\begin{array}{l}\text { Capital } \\
\text { adequacy }\end{array}$ & $\begin{array}{l}\text { Capital Adequacy Ratio }(\mathrm{CAR})=\text { BASEL Ratio } \\
\text { CAR }(\%)=\frac{\text { Total regulatory capital }}{\text { Risk }- \text { weighted assets }}\end{array}$ & $\begin{array}{l}\text { (Altan et al., 2014; Wanke et al., } \\
\text { 2016; Karim et al., 2018) }\end{array}$ \\
\hline Assets quality & $\begin{array}{l}\text { Asset Quality }(\mathrm{AQ})=\text { Gross nonperforming financing } \\
\text { ratio } \mathrm{AQ}(\%)=\frac{\text { Gross nonperforming financing }}{\text { Total financing }}\end{array}$ & $\begin{array}{l}\text { (Sahut and Mili, 2011; Altan et al., } \\
\text { 2014; Lahrech et al., 2014; } \\
\text { Alqahtani et al., 2017) }\end{array}$ \\
\hline Management & $\begin{array}{l}\text { Management }(\mathrm{MAN})=\text { Cost to Income } \\
\operatorname{MAN}(\%)=\frac{\text { Operating costs }}{\text { Gross income }}\end{array}$ & $\begin{array}{l}\text { (Dincer et al., 2011; Peltonen et al., } \\
\text { 2015; Alqahtani et al., 2017; Munir } \\
\text { et al., 2017) }\end{array}$ \\
\hline \multirow[t]{3}{*}{ Earnings } & Return on assets $(\mathrm{ROA}) \mathrm{ROA}(\%)=\frac{\text { Net income }}{\text { Totalassets }}$ & $\begin{array}{l}\text { (Dincer et al., 2011; Wanke et al., } \\
\text { 2016; Alqahtani et al., 2017; Karim } \\
\text { et al., 2018) }\end{array}$ \\
\hline & Return on equity (ROE) ROE $(\%)=\frac{\text { Netincome }}{\text { Equity }}$ & $\begin{array}{l}\text { ( Dincer et al., 2011; Altan et al., } \\
\text { 2014; Lahrech et al., 2014; } \\
\text { Peltonen et al., 2015; Munir et al., } \\
\text { 2017; Karim et al., 2018) }\end{array}$ \\
\hline & Net profit margin $(\mathrm{NPM}) \mathrm{NPM}(\%)=\frac{\text { Net income }}{\text { Gross income }}$ & $\begin{array}{l}\text { (Altan et al., 2014; Wanke et al., } \\
\text { 2016; Karim et al., 2018) }\end{array}$ \\
\hline Liquidity & Liquidity assets ratio (LIQ) LIQ $(\%)=\frac{\text { Liquid assets }}{\text { Total assets }}$ & $\begin{array}{l}\text { (Dincer et al., 2011; Altan et al., } \\
\text { 2014; Lahrech et al., 2014; } \\
\text { Peltonen et al., 2015; Alqahtani } \\
\text { et al., 2017; Karim et al., 2018) }\end{array}$ \\
\hline $\begin{array}{l}\text { Sensitivity to } \\
\text { market risk }\end{array}$ & $\begin{array}{l}\text { Sensitivity to market risks }(\mathrm{SEN})=\text { Net foreign } \\
\text { exchange }(\mathrm{FX}) \text { open position to capital } \\
\mathrm{SEN}(\%)=\frac{\text { Net foreign exchange(FX)open position }}{\text { Total regulatory capital }}\end{array}$ & $\begin{array}{l}\text { (Gasbarro et al., 2002; Dincer et al., } \\
\text { 2011; Roman and Şargu, 2013; } \\
\text { Erol et al., 2014; Hofstetter et al., } \\
\text { 2018; Karim et al., 2018) }\end{array}$ \\
\hline
\end{tabular}

Source(s): Retrieved from the literature
Table 2.

The widely used parameters within CAMELS Model 
IES

28,1

54

Macroeconomics variables. To avoid the issue of bias due to excluded variables, other variables were included in the model to monitor the potential effects of other growth determinants that will be implemented based on the previous studies, trade openness (Trade) (Boukhatem and Moussa, 2018), gross fixed capital formation (GFCF) (Kassim, 2016) and consumer price index (CPI) as a proxy for inflation (Djalilov and Piesse, 2016; Kassim, 2016; Rabaa and Younes, 2016; Zarrouk et al., 2016; Setyawati et al., 2017).

Thus, the estimation variables are:

(1) Dependent variable: GDP.

(2) Independent variables: ROA, ROE, NPM, CAR, LIQ, MAN, SEN.

(3) Control variables: Trade, GFCF, CPI.

\section{Estimating model}

According to the literature review, most studies have agreed to adopt panel regression models such as Panel GMM, Panel regression (fixed-effects), thus, this study applied the panel GMM estimation.

A basic problem in the empirical analysis of economic growth in which control variables must be included in the model. This is the result of what Brock and Durlauf (2001) described as an open-ended theory or causal relationship between a variable and economic growth, this theory indicates that the link between another variable and economic growth cannot be controlled out, that's what Durlauf and Quah (1999) verified before, they introduced over 90 variables for probable economic growth variables.

However, the primary objective in this research is not to contribute to all theories of economic growth, but to examine whether and how financial performance Islamic finance affects economic growth in the frame of endogenous growth. For this purpose, we have specified the minimal model for economic growth. Therefore, following previous studies related to the topic, we have adopted the potential macro-economic factors as control variables to avoid the issue of bias. Therefore, the general model to be estimated within the frame of the endogenous growth model is (Figure 1):

Figure 1.

Summary of the empirical investigation in a frame the endogenous economic growth model

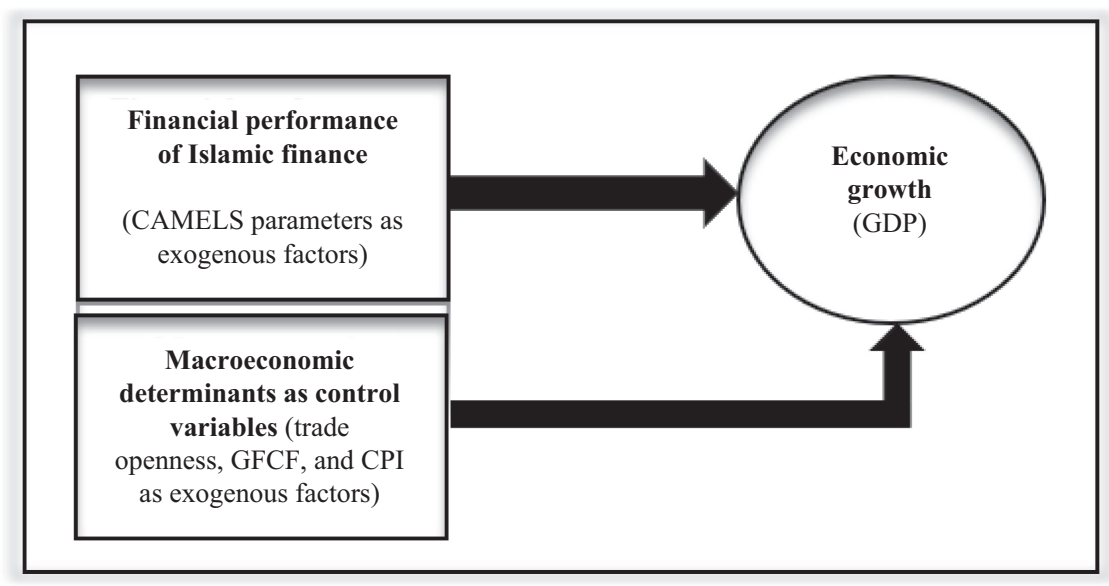

Source(s): Prepared by the authors 


$$
Y_{i t}=\alpha_{0}+\alpha_{i} P_{i t}+\beta_{i} X_{i t}+\xi_{i t} \forall \xi_{i t}=v_{i}+\mu_{i t}
$$

The CAMELS approach

In which:

$Y_{i t}$ is the Economic growth measure for country $i$ at time $t . P_{i t}$ are the financial performance of Islamic finance variables for country $i$ at time $t$.

$X_{i t}$ are the variables of macroeconomics for country $i$ at time $t . \alpha_{0}$ is a constant term, $\alpha_{i}$ and $\beta_{i}$ are coefficients.

$\xi_{i t}$ is an error term, with $v_{\mathrm{i}}$ is the unobserved financial performance of Islamic finance effect and $\mu_{i t}$ the idiosyncratic error.

financial performance of Islamic finance has shown a tendency to persevere over time, due to obstacles to asset quality, market structure failures, and/or macroeconomics shocks on GDP (Athanasoglou et al., 2008). Hence, we adopt a dynamic specification of the model by including a lagged dependent variable among the regressors (Arellano, 2003; Croissant and Millo, 2019), the regression of Eqn (1) augmented with lagged GDP has become:

$$
Y_{i t}=\alpha_{0}+\partial Y_{i, t-1}+\alpha_{i} P_{i t}+\beta_{i} X_{i t}+\xi_{i t}
$$

Where $Y_{i, t-1}$ is the one-quarter lagged GDP and $\partial$ is a coefficient.

\section{Econometric methodology}

The estimation problem raised by the potential existence of unobserved individual effects, the endogeneity, and the correlation between regressors and lagged variables, make fixed or random effects unsuitable for the estimation. Such methods generate bias and inaccurate results (Baltagi and Kao, 2001). Arellano and Bond (1991) estimated the specific model for the first difference, which can remove the unobserved individual effect, in which the estimation uses all existing lagged values of the dependent variable and lagged values of the exogenous regressors as an instrument.

Blundell and Bond (1998) indicated that when the dependent variable and the explanatory variables are determined across time, the lagged levels of these variables are weak instruments for the regression equation of differences. Later they developed a new method called the GMM system estimator that included lagged stages and lagged differences as instruments.

Roodman (2009) and Bond (2002) specified GMM as a system estimation that can resolve the problems correlated to endogeneity, unseen heterogeneity and autocorrelation. Therefore, in this study, the system GMM estimator was applied to conduct the empirical investigation.

According to Roodman (2009), the GMM model is:

$$
Y=x^{\prime} \beta+\varepsilon \forall E(\varepsilon \mid z)=0
$$

In which:

$\beta$ is a support vector of coefficients, $y$ and $\varepsilon$ are random variables, $x=\left(x_{1}, \ldots, x_{k}\right)^{\prime}$ is a column vector of $k$ regressors, $z=\left(z_{1}, \cdots, z_{j}\right)^{\prime}$ is a column vector of $j$ instruments, $x$ and $z$ can share elements and $j \geq k$. We use $X, Y$, and $Z$ to signify matrices of $N$ observations for $x, y$, and $z$, and we state $E=Y-X \beta$. Given an estimation, $\widehat{\beta}$, the experimental residuals are $\widehat{E}=\left(\widehat{e}_{1}, \cdots, \widehat{e}_{N}\right)^{\prime}=Y-X \widehat{\beta}$. We make no statement at this point about $E\left(E E^{\prime} \mid Z\right)=\Omega$ excepting that it exists.

In the GMM, one states that magnitude through a generalized metric, based on a positive semidefinite quadratic form. Let $A$ be the matrix for such a quadratic form. Then the metric is:

$$
\left\|E_{N}(z \varepsilon) A=\right\| \frac{1}{N} z^{\prime} \widehat{E} \| \equiv N\left(\frac{1}{N} z^{\prime} \widehat{E}\right)^{\prime} A\left(\frac{1}{N} z^{\prime} \widehat{E}\right)=\frac{1}{N} \widehat{E}^{\prime} z_{A} z^{\prime} \widehat{E}
$$


IES

28,1

56

To derive the indicated GMM estimate, call it $\widehat{\beta}_{A}$, we resolve the minimization problem: $\widehat{\beta}_{A}=\operatorname{argmin}_{B}\left\|z^{\prime} \widehat{E}\right\| A$ whose solution is determined by $0=d /(\widehat{d} \widehat{\beta})\left\|z^{\prime} \widehat{E}\right\| A$.

The extension of this derivative with chain law is:

$$
0=\frac{d}{d \widehat{\beta}}\left\|Z^{\prime} \widehat{E}\right\| A=\frac{d}{d \widehat{E}}\left\|Z^{\prime} \widehat{E}\right\| A \frac{d \widehat{E}}{d \widehat{\beta}}=\frac{d}{d \widehat{E}}\left\{\frac{1}{N} \widehat{E}^{\prime}\left(Z A Z^{\prime}\right)\right\} \frac{d(Y-X \widehat{\beta})}{d \widehat{\beta}}=\frac{2}{N} \widehat{E}^{\prime} Z A Z^{1}(-X)
$$

The last step is to use identity matrix $d \frac{A b}{d b}=A$ and $d \frac{\left(b^{\prime} A b\right)}{d b}=2 b^{\prime} A$, where $b$ is a column vector, and $A$ is a symmetric matrix. Dropping the factor of $-2 / N$ and transposing,

$$
\begin{aligned}
0 & =\widehat{E} Z A Z^{\prime} X=\left(Y-X \widehat{\widehat{\beta}}_{A}\right)^{\prime} Z A Z^{\prime} X=Y^{\prime} Z A Z^{\prime} X-\widehat{\beta}^{\prime} X^{\prime} Z A Z^{\prime} X \Rightarrow X^{\prime} Z A Z^{\prime} X \widehat{\beta}_{A} \\
& =X^{\prime} Z A Z^{\prime} Y \Rightarrow \widehat{\beta}_{A}=\left(X^{\prime} Z A Z^{\prime} X\right)^{-1} X^{\prime} Z A Z^{\prime} Y
\end{aligned}
$$

This is the GMM estimator is defined by $A$, it is linear in $Y$, whereas $A$ weights moments (Roodman, 2009).

\section{Results and discussion}

Table 3 showed that the effect of return on assets ( $p$-value of ROA: $0.048 \approx 0.05$ ) on economic growth is statistically very closer to the $p$-value 0.05 , so we could not decide whether ROA is strongly significant to the economic growth in a significance level of $5 \%$, but based on a significance level of $10 \%$, we could consider the return on assets significant to the economic growth.

Concerning the impact of return on equity on economic growth (GDP), the impact is statistically significant and positive ( $p$-value of ROE: 0.029 is strongly fewer than 0.05 ) reliably with what Bourke (1989) had confirmed that banks with high profitability remain well-capitalized which cause an increase in capital stock due to the banking profitability, which leads to economic growth according to the endogenous growth theory (Romer, 2011), besides, both studies of Rabaa and Younes (2016) and Tabash (2019) demonstrated the same significant positive link between ROE and GDP.

\begin{tabular}{lccrr}
\hline Variables & Coefficients & Standard Error & $t$-stat & $P>|t|$ \\
\hline Logged GDP & 0.3651691 & 0.2462917 & 1.48 & 0.142 \\
ROA & $-1.28 \mathrm{e}+07$ & 6391176 & -2.01 & 0.048 \\
ROE & 1344551 & 606424.5 & 2.22 & 0.029 \\
NPM & -200432.1 & 130696.4 & -1.53 & 0.129 \\
CAR & 798193.6 & 441092.5 & 1.81 & 0.074 \\
AQ & -58645.37 & 806866.3 & -0.07 & 0.942 \\
MAN & -19133.63 & 81741.79 & -0.23 & 0.816 \\
LIQ & 29910.16 & 84740.73 & 0.35 & 0.725 \\
SEN & -73015.72 & 150586.6 & -0.48 & 0.629 \\
Trade & -117574.8 & 81208.04 & -1.45 & 0.152 \\
GFCF & 0.192758 & 0.3104096 & 0.62 & 0.536 \\
CPI & -762.346 & 372.2433 & -2.05 & 0.044 \\
Constant & 185295.1 & 178750.7 & 1.04 & 0.303
\end{tabular}

Table 3.

Panel system GMM estimation output

Note(s): Number of obs $=92$ Obs per group: $\min =16$; Number of groups $=5$ Number of instruments $=40$; $F(12,79)=145.81$ avg $=18.40$ Prob $>F=0.000 \max =19$

Source(s): Panel system GMM output using STATA 16 
For the effects of other CAMELS financial ratios parameters, (net profit margin (NPM), capital adequacy ratio (CAR), asset quality (AQ), management (MAN), liquidity assets ratio (LIQ), sensitivity to market risks (SEN)) were not statistically significant on economic growth (GDP).

For other macro-economic variables, only the CPI was significant and negative to economic growth reliable to the economic conception ( $p$-value of CPI: 0.044 is fewer than 0.05 ), while trade openness (Trade) and gross fixed capital formation (GFCF) were not significant to the economic growth also, both coefficients of lagged GDP and the constant were not statistically significant.

Regarding the one-step system GMM diagnostics, we have performed the Sargan test of over-identifying restrictions proposed by Arellano and Bond (1991) to test the validity of the instruments as shown in (Table 4).

According to the Sargan test of over-identifying restrictions in Table 4 , the $p$-value is insignificant (Prob $>\chi^{2}=0.849$ ), so all the instruments as a group are exogenous, and the overall validity of instruments is significant.

According to Arellano-Bond test outputs, the error term of the differenced equation is not serially correlated at both of the first order AR (1) $(\operatorname{Pr}>Z=0.099)$ and second-order AR (2) $(\operatorname{Pr}>Z=0.379)$ (see Table 4).

\section{Conclusion}

While most studies have indicated that financial performance of Islamic finance is determined by profitability (Al Khulaifi et al., 1999; Yazdani, 2011; Djalilov and Piesse, 2016; Rabaa and Younes, 2016; Alkhazaleh, 2017; Olson and Zoubi, 2017; Setyawati et al., 2017; Tabash, 2019), this study measured the financial performance of Islamic finance by the CAMELS method to get robust estimated results from the connection between the financial performance of Islamic finance and economic growth in a frame of the endogenous growth model. By applying the panel one-step system GMM method, this study found that only ROE was statistically significant and positive to economic growth (GDP). Therefore, this paper concluded that the financial performance of Islamic finance through profitability had a significant positive impact on economic growth. However, the financial performance of Islamic finance through capital adequacy, assets quality, management, liquidity, sensitivity to market risk, it was not significant to economic growth. As a result, those ratios of the financial performance of Islamic finance are still insufficient to make a positive contribution to economic growth; therefore, Islamic banks should stimulate those performance factors to provide a significant impact on the economic growth.

Serial correlation tests

Arellano - Bond test for AR (1) in first differences

Arellano - Bond test for AR (1) in first differences

$$
\begin{array}{ll}
Z=-1.65 & \operatorname{Pr}>Z=0.099 \\
Z=-0.88 & \operatorname{Pr}>Z=0.379 \\
\chi^{2}(27)=19.55 & \text { Prob }>\chi^{2}=0.849
\end{array}
$$

The overall validity of the instruments

Sargan Test of over-identifying restrictions

Difference-in-Sargan tests of exogeneity of instrument subsets GMM Instruments for levels

Sargan test excluding group Difference (null $\mathrm{H}=$ exogenous)

IV (trade GFCF CPI)

Sargan test excluding group Difference (null $\mathrm{H}=$ exogenous)

The CAMELS

\section{approach}

$-$

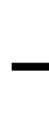


IES

28,1

Choosing to focus on the relationship between financial performance of Islamic finance and economic growth, this paper controlled the empirical model with other macro-economic variables to avoid possible bias; the empirical investigation found that the CPI, which is the proxy variable for inflation is statistically significant and negative for economic growth consistent with the economic conception.

According to this research, which measured the financial performance of Islamic finance using the CAMELS model, profitability (earnings) of Islamic finance is the real explanatory factor that contributes to economic growth. Therefore, by adopting only the profitability as a measure of the financial performance of Islamic finance, this study concludes that there is a positive relationship between financial performance of Islamic finance and economic growth in general consistently with what Tabash (2019) and Rabaa and Younes (2016) had determined. When they employed only the profitability as a measure for the financial performance of Islamic banking sector, they found a positive relationship between the financial performance of Islamic banking sector and economic growth.

In conclusion, as an answer for the question of whether the financial performance of Islamic finance affects economic growth in the frame of the endogenous growth model, the financial performance of Islamic finance contributes and promotes economic growth only through profitability. This result confirmed the concept of endogenous growth theory when the Islamic banks' profitability increases and stimulates investments and the capital stock which leads to economic growth. Correspondingly, the indicated result is an extension for the classical concept of the supply-leading hypothesis of Schumpeter identifications (Schumpeter and Redvers, 1934), and the theory of financial repression which determined that financial development leads to economic growth (McKinnon, 1973; Shaw, 1973). However, the financial performance of Islamic finance does not contribute to economic growth through other factors of capital adequacy, assets quality, management, liquidity and sensitivity to market risk.

\section{Implications for research and practice:}

This study has some implications for research and practice as the following:

(1) This study aims to investigate empirically the link between the financial performance of Islamic finance and economic growth using CAMELS parameters as a robust measure for the financial performance of Islamic finance in a frame of the endogenous growth model. Thus, the empirical investigation in this paper would fill the literature gap by addressing the effect of the financial performance of Islamic finance on economic growth. Therefore, this study could support the academians, researchers and decision-makers who want to achieve economic growth through stimulating Islamic finance in the banking sector.

(2) Regarding methodology, this study may well be extended to investigate empirically the link between the financial performance of Islamic finance and economic growth over the $Z$-score model as another measure for the financial performance of Islamic finance.

(3) In terms of practical implication, this paper provides important evidence for policymakers, regulators, associated authorities and decision-makers across countries to enhance other financial performance factors of Islamic finance (capital adequacy, assets quality, management, liquidity and sensitivity to market risk) to reach a significant economic growth through Islamic banks' channels in the financial market. 


\section{References}

Adekola, O.A. (2016), "The effect of banks profitability on economic growth in Nigeria", Journal of Business and Management, Vol. 18 No. 3, pp. 1-9.

Al Khulaifi, A., Al Sulaiti, K. and Al Khatib, F. (1999), Banking Performance and Economic Growth in Qatar: An Empirical Investigation.

Alharbi, A.T. (2017), "Determinants of Islamic banks' profitability: international evidence", International Journal of Islamic and Middle Eastern Finance and Management. doi: 10.1108/ IMEFM-12-2015-0161.

Alkhazaleh, A.M.K. (2017), "Does banking sector performance promote economic growth?”, Case study of Jordanian commercial banks", Problems and Perspectives in Management, Vol. 15 No. 2, pp. 55-66.

Alqahtani, F., Mayes, D.G. and Brown, K. (2017), "Reprint of economic turmoil and Islamic banking: evidence from the gulf cooperation council”, Pacific-Basin Finance Journal, Vol. 42, pp. 113-125.

Altan, M., Yusufazari, H. and Bedük, A. (2014), "Performance analysis of banks in Turkey using CAMEL approach", Proceedings of International Academic Conferences, International Institute of Social and Economic Sciences, Vol. 2.

Arellano, M. (2003), Panel Data Econometrics, Oxford University Press.

Arellano, M. and Bond, S. (1991), "Some tests of specification for panel data: Monte Carlo evidence and an application to employment equations", The Review of Economic Studies, Vol. 58 No. 2, pp. 277-297.

Athanasoglou, P.P., Brissimis, S.N. and Delis, M.D. (2008), "Bank-specific, industry-specific and macroeconomic determinants of bank profitability", Journal of International Financial Markets, Institutions and Money, Vol. 18 No. 2, pp. 121-136.

Baltagi, B.H. and Kao, C. (2001), "Nonstationary panels, cointegration in panels and dynamic panels: a survey", Book-Part, 13 February. doi: 10.1016/S0731-9053(00)15002-9.

Bikker, J.A. and Hu, H. (2002), "Cyclical patterns in profits, provisioning and lending of banks and procyclicality of the new Basel capital requirements", PSL Quarterly Review, Vol. 55 No. 221, pp. 143-175.

Blundell, R. and Bond, S. (1998), "Initial conditions and moment restrictions in dynamic panel data models", Journal of Econometrics, Vol. 87 No. 1, pp. 115-143.

Bond, S.R. (2002), "Dynamic panel data models: a guide to micro data methods and practice"', Portuguese Economic Journal, Vol. 1 No. 2, pp. 141-162.

Boukhatem, J. and Moussa, F.B. (2018), "The effect of Islamic banks on GDP growth: some evidence from selected MENA countries", Borsa Istanbul Review, Vol. 18 No. 3, pp. 231-247.

Bourke, P. (1989), "Concentration and other determinants of bank profitability in Europe, North America and Australia”, Journal of Banking \& Finance, Vol. 13 No. 1, pp. 65-79.

Brock, W.A. and Durlauf, S.N. (2001), "What have we learned from a decade of empirical research on growth? Growth empirics and reality", The World Bank Economic Review, Vol. 15 No. 2, pp. $229-272$.

Christopoulos, A.G., Mylonakis, J. and Diktapanidis, P. (2011), "Could Lehman Brothers' collapse be anticipated? An examination using CAMELS rating system", International Business Research, Vol. 4 No. 2, p. 11.

Croissant, Y. and Millo, G. (2019), Panel Data Econometrics with R, Wiley Online Library.

Demirgüç-Kunt, A. and Huizinga, H. (1999), "Determinants of commercial bank interest margins and profitability: some international evidence", The World Bank Economic Review, Vol. 13 No. 2, pp. 379-408.

Dincer, H., Gencer, G., Orhan, N. and Sahinbas, K. (2011), "A performance evaluation of the Turkish banking sector after the global crisis via CAMELS ratios", Procedia - Social and Behavioral Sciences, Vol. 24, pp. 1530-1545.

The CAMELS approach 
IES

28,1

60

Djalilov, K. and Piesse, J. (2016), "Determinants of bank profitability in transition countries: what matters most?", Research in International Business and Finance, Vol. 38, pp. 69-82.

Durlauf, S.N. and Quah, D.T. (1999), The new empirics of economic growth, Handbook of Macroeconomics, Vol. 1, pp. 235-308.

Erol, C., Baklaci, H.F., Aydoğan, B. and Tunç, G. (2014), "Performance comparison of Islamic (participation) banks and commercial banks in Turkish banking sector", EuroMed Journal of Business, doi: 10.1108/EMJB-05-2013-0024.

Gasbarro, D., Sadguna, I.G.M. and Zumwalt, J.K. (2002), "The changing relationship between CAMEL ratings and bank soundness during the Indonesian banking crisis", Review of Quantitative Finance and Accounting, Vol. 19 No. 3, pp. 247-260.

GDP - Gross, B. (2018), Domestic Product 2018, countryeconomy.com, available at: https:// countryeconomy.com/gdp/brunei (accessed 19 January 2020).

Hofstetter, M., Lopez, J.I. and Urrutia, M. (2018), "Limits to Foreign Exchange Net Open Positions and Capital Requirements in Emerging Economies”, Documento CEDE, No. 2018-10, doi: 10.2139/ ssrn.3116943.

IMF, A. (2000), Macroprudential Indicators of Financial System Soundness, Occasional Paper.

Islamic Finance Development Report 2018 (2018), Thomson Reuters, available at: https://www. smefinanceforum.org/post/islamic-finance-development-report-2018 (accessed 11 February 2020).

Jhingan, M.L. (2011), The Economics of Development and Planning, Vrinda Publications, Delhi.

Karim, N.A., Alhabshi, S.M.S.J., Kassim, S. and Haron, R. (2018), "Measuring bank stability: a comparative analysis between Islamic and conventional banks in Malaysia", Proceedings of the 2nd Advances in Business Research International Conference, Springer, pp. 169-177.

Kassim, S. (2016), "Islamic finance and economic growth: the Malaysian experience", Global Finance Journal, Vol. 30, pp. 66-76.

Khan, M.M.S., Ijaz, F. and Aslam, E. (2014), "Determinants of profitability of Islamic banking industry: an evidence from Pakistan”, Business and Economic Review, Vol. 6 No. 2, pp. 27-46.

Lahrech, N., Lahrech, A. and Boulaksil, Y. (2014), "Transparency and performance in Islamic banking", International Journal of Islamic and Middle Eastern Finance and Management, doi: 10.1108/IMEFM-06-2012-0047.

Masood, O., Ghauri, S.M.K. and Aktan, B. (2016), "Predicting Islamic banks performance through CAMELS rating model”, Banks and Bank Systems, Vol. 11 No. 3, pp. 37-43.

McKinnon, R.I. (1973), Money and Capital in Economic Development, Brookings Institution Press.

Munir, B., Salwa, U. and Bustamam, A. (2017), "Camel ratio on profitability banking performance (Malaysia versus Indonesia)", International Journal of Management, Innovation and Entrepreneurial Research, Vol. 3 No. 1, pp. 30-39.

Olson, D. and Zoubi, T. (2017), "Convergence in bank performance for commercial and Islamic banks during and after the global financial crisis", The Quarterly Review of Economics and Finance, Vol. 65, pp. 71-87.

Peltonen, T.A., Constantin, A. and Sarlin, P. (2015), "Network linkages to predict bank distress", SSRN, 2579584.

Petkovski, M. and Kjosevski, J. (2014), "Does banking sector development promote economic growth? An empirical analysis for selected countries in Central and South Eastern Europe", Economic Research-Ekonomska Istraživanja, Vol. 27 No. 1, pp. 55-66.

Rabaa, B. and Younes, B. (2016), "The impact of the Islamic banks performances on economic growth: using panel data", International Journal of Economics and Finance Studies, Vol. 8 No. 1, pp. 101-111.

Rashid, A. and Jabeen, S. (2016), "Analyzing performance determinants: conventional versus Islamic banks in Pakistan”, Borsa Istanbul Review, Vol. 16 No. 2, pp. 92-107. 
Rashid, A., Khaleequzzaman, M. and Jabeen, S. (2015), “'Analyzing performance of banks in Pakistan : conventional versus Islamic banks", Journal of Islamic Business and Management, Riphah Centre of Islamic Business, Vol. 219 No. 3327, pp. 1-26.

Reuters, T. (2020), State of the Global Islamic Economy Report 2019/20 Thomson Reuters, Dinar Standard, available at: https://www.salaamgateway.com/SGIE19-20 (accessed 3 January 2020).

Rodica-Oana, I. (2014), “The evolution of Romania's financial and banking system”, Procedia Economics and Finance, Vol. 15, pp. 760-768.

Roman, A. and Şargu, A.C. (2013), "Analysing the financial soundness of the commercial banks in Romania: an approach based on the camels framework", Procedia Economics and Finance, Vol. 6, pp. 703-712.

Romer, D. (2011), “Endogenous Growth”, Advanced Macroeconomics, 4th ed., McGraw-Hill, New York, NY, pp. 101-149.

Roodman, D. (2009), "How to do xtabond2: an introduction to difference and system GMM in Stata", The Stata Journal, Vol. 9 No. 1, pp. 86-136.

Rostami, M. (2015), "Determination of Camels model on bank's performance", International Journal of Multidisciplinary Research and Development, Vol. 2 No. 10, pp. 652-664.

Rozzani, N. and Rahman, R.A. (2013), "Camels and performance evaluation of banks in Malaysia: conventional versus Islamic", Journal of Islamic Finance and Business Research, Vol. 2 No. 1, pp. 36-45.

Sahut, J.-M. and Mili, M. (2011), "Banking distress in MENA countries and the role of mergers as a strategic policy to resolve distress", Economic Modelling, Vol. 28 No. 1, pp. 138-146.

Schumpeter, J.A. and Redvers, O. (1934), Theorie Der Wirtschaftichen Entwicklung. The Theory of Economic Development. An Inquiry into Profits, Capital, Credit, Interest, and the Business Cycle, TranslatedRedvers Opie.

Setyawati, I., Suroso, S., Suryanto, T. and Nurjannah, D.S. (2017), "Does financial performance of Islamic banking is better? Panel Data Estimation", European Research Studies, Vol. 20 No. 2, p. 592.

Shaw, E.S. (1973), Financial Deepening in Economic Development.

State of the Global Islamic Economy Report 2018/19 (2018), Thomson Reuters, Dinar Standard, available at: https://www.salaamgateway.com/story/state-of-the-global-islamic-economy-report201819-islamic-economy-marks-steady-growth (accessed 18 January 2020).

Tabash, M.I. (2019), "Banking sector performance and economic growth: an empirical evidence of UAE Islamic banks", Creative Business and Social Innovations for a Sustainable Future, Springer, pp. 39-45.

Tabash, M.I. and Anagreh, S.A. (2017), "Do Islamic banks contribute to growth of the economy?", Evidence from United Arab Emirates (UAE)”, Banks and Bank Systems, Vol. 12 No. 1, pp. 113-118.

Tabash, M.I. and Dhankar, R.S. (2014), "The impact of global financial crisis on the stability of Islamic banks: empirical evidence”, Journal of Islamic Banking and Finance, Vol. 2 No. 1, pp. 367-388.

Trading Economics Report (2019a), available at: https:/tradingeconomics.com/malaysia/gdp-growthannual (accessed 19 January 2020).

Trading Economics Report (2019b), available at: https:/tradingeconomics.com/turkey/gdp-growth (accessed 19 January 2020).

Trading Economics Report (2019c), available at: https://tradingeconomics.com/saudi-arabia/gdpgrowth-annual (accessed 19 January 2020).

Wanke, P., Azad, Md.A.K. and Barros, C.P. (2016), "Financial distress and the Malaysian dual baking system: a dynamic slacks approach", Journal of Banking and Finance, Vol. 66, pp. 1-18. 
IES

28,1

62

World Bank, G. (2019), Indonesia Maintains Steady Economic Growth in 2019, World Bank Group, available at: https://www.worldbank.org/en/news/press-release/2019/07/01/indonesia-maintainssteady-economic-growth-in-2019 (accessed 19 January 2020.

Yazdani, M. (2011), "Role of performance of privately owned banks in economic growth of Iran", Aust. J. Basic Appl. Sci, Vol. 5 No. 1, pp. 695-700.

Zarrouk, H., Jedidia, K.B. and Moualhi, M. (2016), "Is Islamic bank profitability driven by same forces as conventional banks?", International Journal of Islamic and Middle Eastern Finance and Management. doi: 10.1108/IMEFM-12-2014-0120.

\section{Corresponding author}

Mohammed Ayoub Ledhem can be contacted at: ledhem.edu@gmail.com

For instructions on how to order reprints of this article, please visit our website:

www.emeraldgrouppublishing.com/licensing/reprints.htm

Or contact us for further details: permissions@emeraldinsight.com 